\title{
EKSPLORASI KERTAS KARTON DALAM PRODUK KEMASAN TAHAN AIR
}

\author{
Martiyadi Nurhidayat ${ }^{1}$, Hardy Adiluhung ${ }^{2}$ \\ Program Studi Desain Produk ${ }^{1,2}$ \\ Telkom University 1,2 \\ martiyadi@telkomuniversity.com ${ }^{1}$, hardydil@telkomuniversity.ac.id ${ }^{2}$
}

\begin{abstract}
Abstrak
Negara yang maju adalah bangsa yang dapat memanfaatkan sampah yang tidak terpakai menjadi dapat digunakan kembali. Pengelolaan dari awal hingga menjadi produk baru merupakan kewajiban manusia untuk dapat menghargai dirinya, alam dan seisin ya. Kertas untuk packaging dengan bahan kertas karton banyak yang menjadi sampah dan biasanya didaur ulang untuk menjadi kertas baru. Penelitian ini menggunakan metode kualitatif dengan pendekatan eksplorasi dengan menggunakan media pertama yaitu kertas karton single ply hingga triple ply dan media kedua sebagai pelapis yang terdiri dari lem kayu dan paraffin untuk memperlihatkan pelapis mana yang lebih tahan terhadap air dan kelembapan. Hasil dari eksplorasi memperlihatkan jika kertas karton yang terkena tetesan air maka daya serap karton kurang dari 5 menit karton sudah basah. Jika kertas karton telah dilapisi lem kayu maka kurang dari 18 jam air sudah masuk kedalam karton, jika kertas karton telah dilapisi paraffin lebih dari 24 jam air tidak masuk kedalam kertas karton. Terdapat kekurangan dari kertas karton yang menggunakan lem kayu yaitu warna air berubah menjadi putih hasil yang didapat bahwa air mengandung kima yang berbahaya jika masuk kedalam tubuh maka perlu dilakukan treatmen yang dilakukan pengujian dengan paraffin maka post test mendapatkan hasil bahwa kertas karton jika dilapisi paraffin akan tahan terhadap air dan kelembapan, intensitas daur ulang sampah karton akan sedikit karena memiliki struktur kuat dan kaku. Luaran pada penelitian ini menjadi solusi untuk produk kemasan yang disimpan atau proses pengiriman seperti penyimpanan digudang, toko yang tidak menggunakan palet kayu, dan pengiriman packing pengiriman barang.
\end{abstract}

Kata Kunci: Kertas Karton, Eksplorasi, Tahan Air.

\section{Abstract}

A developed country is a nation that can use unused wastage to be reusable. Management from the beginning to become a new product is a human obligation to be able to respect himself, nature, and everything in it. A lot of paper for packaging with cardboard material becomes garbage and is usually recycled to become new paper. This study uses a qualitative method with an exploratory approach using the first medium, namely single ply to triple-ply cardboard, and the second media as a coating consisting of wood glue and paraffin to show which coating is more resistant to water and moisture. The results of the exploration show that if the cardboard is exposed to water droplets, the absorption capacity of the cardboard is less than 5 minutes the cardboard is already wet. If the paperboard has been coated with wood glue, then in less than 18 hours the water has entered the carton, if the paperboard has been coated with paraffin for more than 24 hours, the water will not enter the cardboard. There is a shortage of cardboard that uses wood glue, namely the color of the water changes to white, the results obtained are that the water contains chemicals that are dangerous if it enters the body, it is necessary to carry out a treatment that is carried out by testing with paraffin, the post-test results show that the paperboard if coated with paraffin will hold up against water and moisture, the intensity of recycling cardboard waste will be less because it has a strong and rigid structure. The output in this research is a solution for packaged products that are stored or the delivery process such as warehouse storage, shops that do not use wooden pallets, and shipping packing for shipping goods.

Keywords: Paperboard, Exploration, Waterproof.

\section{PENDAHULUAN}

Negara yang maju adalah negara yang dapat memanfaatkan sampah menjadi produk yang dapat dijual kembali atau memanfaatkan sebagai energy. Berbeda lagi jika negara tidak dapat mengelola daur ulang sampah maka sampai kapanpun yang menghancurkan bangsanya sendiri. Indonesia diperkirakan menghasilkan 64 juta ton sampah setiap tahun. Berdasarkan data Kementerian Lingkungan Hidup dan Kehutanan (KLHK), komposisi sampah didominasi oleh sampah organik, yakni mencapai $60 \%$ dari total sampah.Sampah plastik menempati posisi kedua dengan $14 \%$ disusul sampah kertas $9 \%$ dan karet 5,5\%. Sampah lainnya terdiri atas logam, kain, kaca, dan jenis sampah lainnya.(Kementerian Lingkungan Hidup dan Kehutanan, 2017) [1].

Banyak kelompok kecil maupun besar yang mengolah sampah tersebut menjadi bahan utama untuk pembuatan produk guna. Hal tersebut sangat membantu dalam kelangsungan hidup manusia. Akan tetapi budaya atau kebiasaan manusia Indonesia yang membuang sampah secara dicampur seperti sampah didalamnya ada sampah dapur, organic, sampah kimia, kaca, logam dll. Menjadikan banyak tahapan pekerjaan yang harus dipisahkan terlebih dahulu hingga ke tempat daur ulang.

Penebangan pohon di hutan yang terus-menerus dilakukan untuk memanfaatkan kayu sebagai produk kertas, tissue, mebel, dan sebagainya. Banyaknya industry yang sudah lulus sertifikasi lingkungan yang menjadikan iperhatian adalah proses penanaman kembali pohon tetapi durasi perkembangan pohon yang cukup lama sedangkan produksi industry dilakukan secara terus menerus maka perlu strategi dan perencanaan yang sangat matang, sebagai contoh PT.ABC merupakan perusahaan manufaktur yang bergerak pada bidang produksi kertas. Perusahaan ini memproduksi jenis kertas karton ivory (Ivory Coated Board) dengan kapasitas produksi mencapai 411 ton/hari atau 150.000 ton/tahun. Pemasaran 
produk PT. ABC antara lain : 30\% untuk ekspor, 20\% untuk lokal, dan 50\% untuk pemasok sebuah perusahaan rokok [2].

Sebagian besar produk dikemas menggunakan kertas kartonatau kertas karton, karena kertas kartonyang biasa digunakan sebagai packaging lebih aman terhadap produk. Produk yang dimanfaatkan oleh pengguna dan kertas kartonyang menjadi sampah/limbah merupakan siklus yang terus menerus dilakukan sebagian manusia dalam berkonsumsi sebuah produk. Sampah / limbah menjadikan hambatan jika tidak ada proses daur ulang dalam mengolah sampah menjadi sebuah produk baru. Kertas kartonterbuat dari kertas kraf liner yang di gabungkan dengan medium. Kertas dibuat dari pohon yang diambil kayunya seperti kayu pinus dan kayu cemara. Maka kertas kartonmasih menggunakan plup dari serat kayu sebagai bahan utamanya yang beratnya 200 gram, sama sepertinya pembuatan kertas. Jika tidak adanya daur ulang dan pembaharuan terhadap kertas kartonmaka untuk menghasilkan kertas kartonperlu memotong pohon sebagai pembuatan cardboard. Sedangkan pohon merupakan sumber oksigen dibumi untuk kehidupan manusia.

Packaging yang menggunakan kertas Kertas kartonjika disimpan terlalu lama dengan kapasitas suhu yang cukup lembab maka akan berdampak pada packaging nya seperti kertas Kertas kartonmenjadi basah, rusak, tidak kuat, dan berjamur yang dampaknya akan merusak produk didalamnya. Perlunya inovasi dalam perubahan atau penambahan dalam Kertas kartonhingga dapat tahan air.

\section{TINJAUAN PUSTAKA}

Kertas merupakan produk dengan ukuran tipis yang dihasilkan oleh serat alami yang mengandung selulosa dan hemiselulosa dari bubur kayu [3]. Kertas baru digunakan untuk berbgai jenis sesuai karakter kebutuhannya. Secara umum, kertas dibedakan menjadi 3 jenis, yaitu kertas coated, kertas semi- coated dan kertas uncoated serta kertas koran [3].

Menurut Kotler \& Keller, pengemasan adalah kegiatan merancang dan memproduksi wadah atau bungkus sebagai sebuah produk [4]. Kemasan adalah desain kreatif yang mengaitkan bentuk, struktur, material, warna, citra, tipografi dan elemen-elemen desain dengan informasi produk agar produk dapat dipasarkan. Kemasan digunakan untuk membungkus, melindungi, mengirim, mengeluarkan, menyimpan, mengidentifikasi dan membedakan sebuah produk di pasar [5]. Biasanya fungsi utama dari kemasan adalah untuk menjaga produk. Namun, sekarang kemasan menjadi faktor yang cukup penting sebagai alat pemasaran [6].

1. Fungsi Kemasan

Perusahaan sangat memperhatikan pembungkus suatu barang, mereka beranggapan bahwa kemasan tidak hanya sebagai pembungkus, tetapi lebih luas dari pada itu. Simamora mengemukakan fungsi kemasan diantaranya yaitu Fungsi Protektif, dan Fungsi Promosional [7].

TABEL I

FUNGSI KEMASAN DALAM PENYIMPANAN

\begin{tabular}{|l|l|l|l|}
\hline Penyimpanan & Benar & &
\end{tabular}

2. Jenis Kemasan

Berdasarkan struktur isi, kemasan dibagi menjadi tiga jenis, yaitu:

a. Kemasan Primer, yaitu bahan kemas langsung mewadahi bahan pangan (kaleng susu, botol minuman, dll).

b. Kemasan Sekunder, yaitu kemasan yang fungsi utamanya melindungi kelompok kemasan lainnya, seperti misalnya kotak karton untuk wadah kaleng susu, kotak kayu untuk wadah buah-buahan yang dibungkus dan sebagainya.

c. Kemasan Tersier dan Kuarter, yaitu kemasan yang diperlukan untuk menyimpan, pengiriman atau identifikasi. Kemasan tersier umumnya digunakan sebagai pelindung selama pengangkutan. 
3. Jenis Kertas kartonYang Digunakan

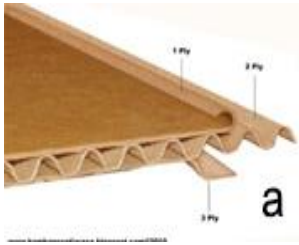

.<smiles>[IH2]</smiles>

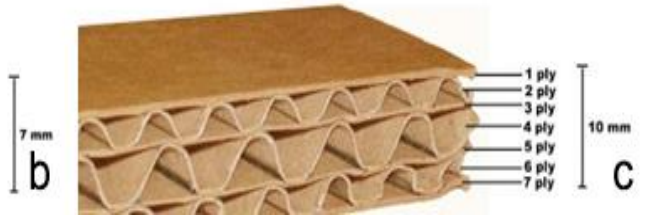

Gambar 1. A-Single Wall, B-Double Wall, C-Triple Wall

Bahan single wall terdiri dari tiga bagian kertas ( 3 ply ), bahan karton ini biasanya dipakai untuk packing barang elektronik, mainan, makanan,minuman, layer/pembatas, dll. Bahan double wall terdiri dari tujuh bagian kertas ( 7 ply ) dengan ketebalan $7 \mathrm{~mm}$, bahan karton ini biasanya dipakai untuk packing barang elektronik, mainan, makanan,minuman, baju, dll. Bahan Tripple wall terdiri dari sepuluh bagian kertas ( 10 ply ) dengan ketebalan 10 $\mathrm{mm}$, bahan karton ini biasanya dipakai untuk packing barang-barang yang berat seperti pakaian untuk export.

\section{METODE PENELITIAN}

Metode eksperimen sebagai metode dengan bentuk sistematis dengan tujuan untuk mencari pengaruh variable satu dengan variabel lain untuk memberikan perlakuan khusus dan pengendalian yang ketat dalam suatu kondisi. Menurut Sugiono, memiliki desain spesifik, jelas, rinci, ditentukan secara mantap dan menjadi pegangan langkah demi langkah dengan menggunakan desain eksplorasi yang berupa Pre-Experiment [8]. Pendekatan eksperimen adalah suatu penelitian yang berusaha mencari pengaruh variable tertentu terhadap variable yang lain dalam kondisi yang terkontrol secara ketat [9]. Desain penelitian yang digunakan adalah desain pre-eksperiment one group pre-test - post-test. Desain ini melibatkan satu kelompok yang diberi pre-test $(\mathrm{O})$, diberi treatment $(\mathrm{X})$ dan diberi post-test. Keberhasilan treatment ditentukan dengan membandingkan nilai pre-test dan nilai post-test.

TABEL II

PRE-EKSPERIMENT ONE GROUP PRE-TEST - POST-TEST
\begin{tabular}{|c|c|c|}
\hline $\mathrm{O}_{1}$ & $\mathrm{X}$ & $\mathrm{O}_{2}$ \\
\hline \multicolumn{3}{|c}{ Sumber : $[10]$}
\end{tabular}

Keterangan

$\mathrm{O}_{1}=$ pre-test

$\mathrm{X}=$ treatment

$\mathrm{O}_{2}=$ post-test

Eksplorasi adalah mengadakan kegiatan percobaan untuk melihat sesuatu hasil [11[. Dengan demikian hasil akan lebih akurat dikarenakan dapat menjadi pembanding dengan keadaan sebelum diberi perlakuan.adapun alur eksplorasi yang telah di buat oleh peneliti sebagai berikut:

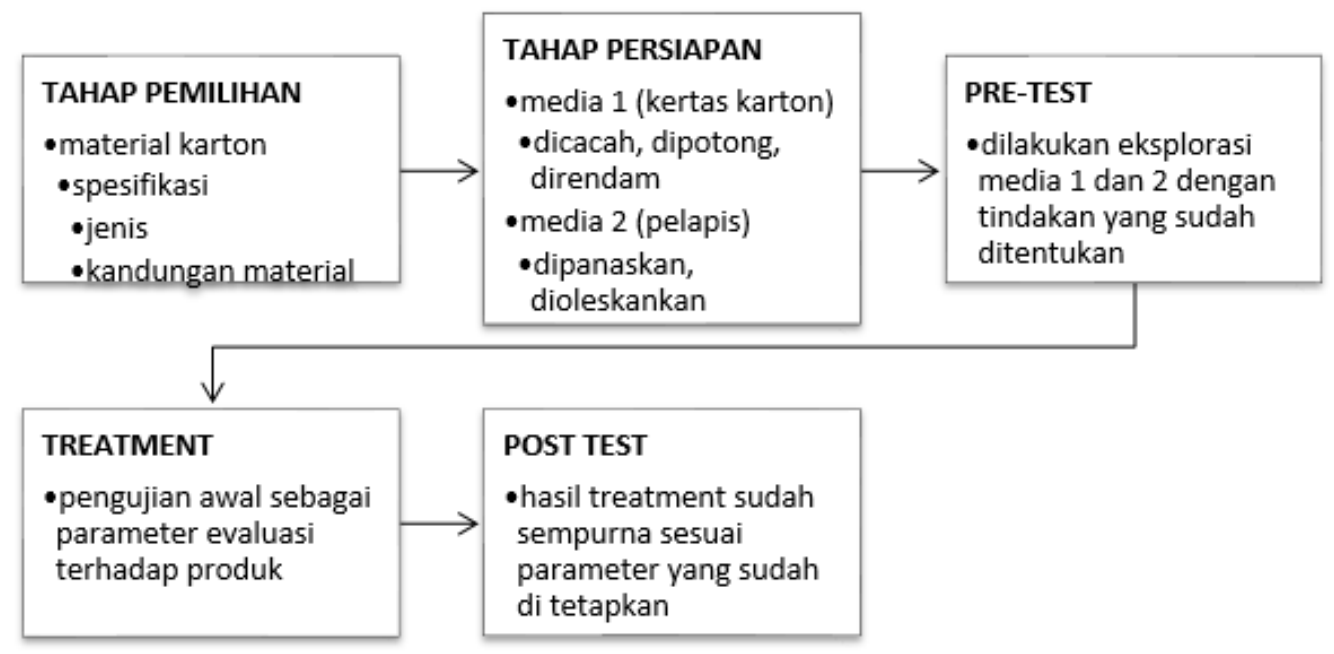

Gambar 2. Alur Metode Dan Perancangan Analisis Penelitian Sumber: Peneliti 


\section{ANALISIS DAN PEMBAHASAN}

Analisis dilakukan sesuai metode penelitian dan petunjuk teknis yang sudah di rancang sebelumnya, hal ini terdapat indicator keberhasilan ialah produk kemasan pada eksplorasi ini harus tahan terhadap kelembapan. Untuk pelaksanaan eksplorasi sebagai besic dilakukan pemotongan kertas karton dengan ukuran yang bervariasi kurang lebih $3 \mathrm{~cm} \times 2 \mathrm{~cm}$ sebagai sempel atau percobaan yang akan dilapisi dengan lapisan tahan air dari produk yang tidak biasa yaitu dari parafin dan dari lem kayu hal ini karena memiliki lapisan yang tidak bisa bergabung dengan air dalam jangka waktu tertentu. Media 1 (a) yang sudah dipotong merupakan sempel yang akan ditindak dengan cara di oleskan dengan lem kayu hingga kering selanjutnya media 1 (b) dioleskan paraffin yang sudah dicairkan dan didiamkan hingga benar benar kering.

\section{Pretest}

Media 1 (a dan b) sudah melakukan tindakan dengan media 2 yaitu pelapis, dimana Tindakan tersebut merupakan pre-test, selanjutnya media 1 yang sudah dikeringkan diberi air dengan cara diteteskan dan menunggu hingga 24 jam untuk mengetahui hasilnya. Maka klasifikasi hasil pretest sebagai berikut

TABEL III

HASIL PRE-TEST EKSPLORASI TERHADAP FISIK KERTAS KARTON

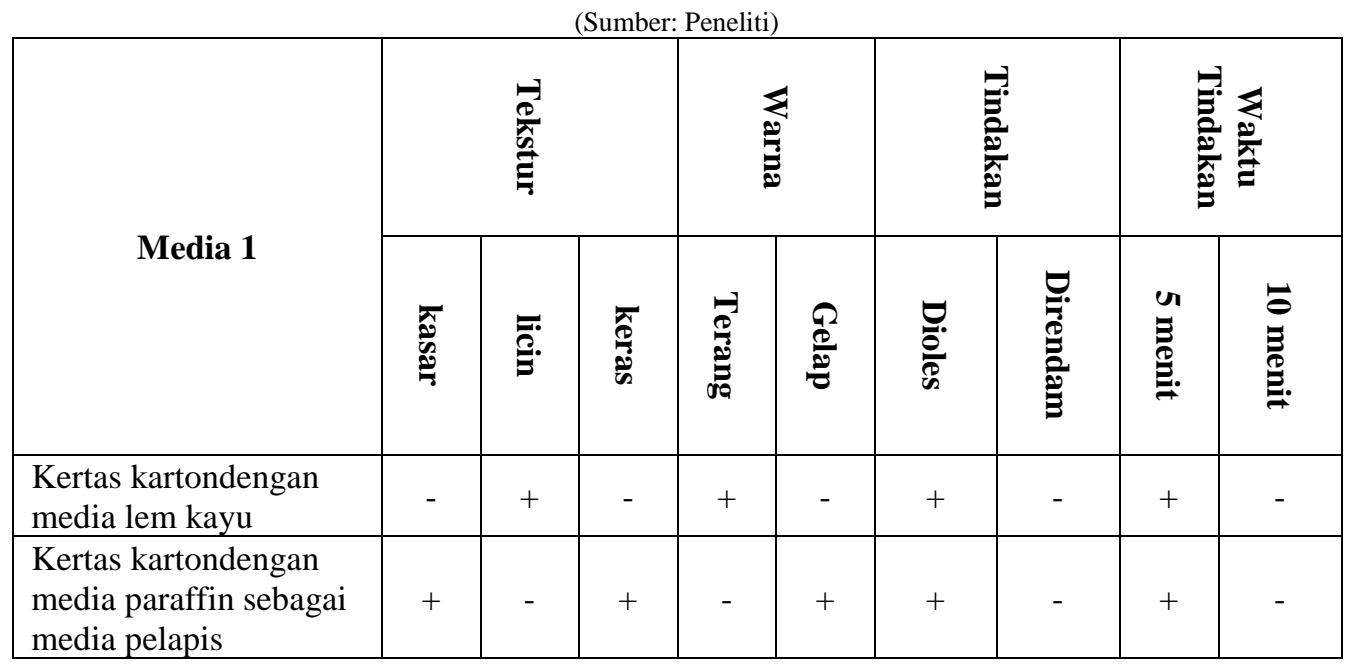

Hasil eksperiman ini memiliki effect secara visual Kertas karton dengan media lem kayu bertekstur Licin dan mengkilat dengan warna Distorsi warna menjadi gelap dari warna sebelumnya dengan tindakan seperti Dioleskan lem kayu pada bagian permukaan atas, bawah, samping kiri dan kanan. Sedangkan Kertas kartondengan media paraffin sebagai media pelapis dengan tekstur keras, kasar, licin, kaku, warna menjadi gelap dari warna sebelumnya tindakannya seperti dioleskan paraffin yang panas.

TABEL IV

TAHAP UJI EKSPLORASI (Sumber: Peneliti)

\begin{tabular}{|l|c|c|l|l|}
\hline \multicolumn{1}{|c|}{ Media 1 } & Media 2 & Waktu & \multicolumn{1}{c|}{ Efek } & Hasil \\
\hline $\begin{array}{l}\text { Kertas karton } \\
\text { ukuran 3cm x 2cm }\end{array}$ & Tanpa pelapis & $03: 51$ detik & $\begin{array}{l}\text { Kertas kartonyang tidak } \\
\text { menggunakan pelapis, perlahan } \\
\text { lahan air masuk kedalam } \\
\text { permukaan ply. }\end{array}$ \\
\hline $\begin{array}{l}\text { Kertas karton } \\
\text { ukuran 3cm x 2cm }\end{array}$ & Lem Kayu & 18 jam & $\begin{array}{l}\text { Warna air berubah menjadi putih, } \\
\text { kertas kartontidak menyerap air }\end{array}$ \\
\hline $\begin{array}{l}\text { Kertas karton } \\
\text { ukuran 3cm x 2cm }\end{array}$ & Paraffin & Lebih dari & $\begin{array}{l}\text { Warna air dalam kondisi normal, } \\
\text { kertas kartontidak menyerap air. }\end{array}$ & \\
\hline
\end{tabular}

Hasil eksplorasi dapat dilihat pada table diatas setelah dilakukan eksplorasi, yang berubah, contohnya yang dilapisi oleh lem kayu karena ketika di beri air kertas karton yang lapisan atas terkikis oleh air sehingga air menjadi warna putih, tetapi kertas karton tidak tembus kedalam kertas karton selama 18 jam. Waktu atau durasi yang unggul 
adalah kertas karton dengan lapisi paraffin. Karena lapisan mengeras dan menjadi kaku ketika menggunakan paraffin sebagai pelapis karton.

TABEL V

HASIL UJI COBA EKSPLORASI

(Sumber: Peneliti)

\begin{tabular}{|l|ll|l|}
\hline \multicolumn{1}{|c|}{ Kertas Karton } & \multicolumn{1}{|c|}{ Kekurangan } & \multicolumn{1}{c|}{ Kelebihan } \\
\hline Pelapis lem kayu & $\bullet \begin{array}{l}\text { Lapisan berulang ulang } \\
\text { Tahan air sampai 18 jam } \\
\end{array}$ & $\begin{array}{l}\text { Tembus air jika lapisan tidak } \\
\text { rapih }\end{array}$ & Masih bisa dilipat \\
\hline Pelapis parafin & $\bullet$ Kaku & $\bullet \begin{array}{l}\text { Kuat } \\
\text { Anti Air lebih dari 24 jam }\end{array}$ \\
\hline
\end{tabular}

Setelah melakukan eksplorasi maka terdapat kelebihan dan kekurangan, kelebihannya untuk pelapis lem kayu kertas karton masih bisa dilipat sedangkan kekurangannya lapisan berulang ulang, tahan air sampai 18 jam, tembus air jika lapisan tidak rapih sedangkan kertas kartondengan menggunakan pelapis paraffin kekurangnyannya kertas kartonkaku, sedangkan kelebihannya Kuat dan Anti Air lebih dari 24 jam. Memungkinkan jika kertas kartondengan pelapis parafin dibuat kemasan untuk melapisi produk .

\section{Treatment}

Dilihat dari hasil tersebut mendapatkan evaluasi yang perlu di treatment antara media 1, media 2, dan teknik yang diaplikasikan kedalam material utama yaitu kertas karton, Adapun penjelasannya seperti berikut:

$$
\text { TABEL VI }
$$

\section{TREATMENT TERHADAP EKSPLORASI TERHADAP MEDIA}

\begin{tabular}{|c|c|c|c|}
\hline & \\
\hline & & & Evidence eksplorasi \\
\hline Keterangan & $\begin{array}{l}\text { Media } 1 \text { (karton tanpa } \\
\text { tindakan media 2) }\end{array}$ & $\begin{array}{l}\text { Media } 1 \text { (karton dengan } \\
\text { tindakan media } 2 \text { lem kayu ) }\end{array}$ & $\begin{array}{l}\text { Media } 1 \text { (karton dengan } \\
\text { tindakan media } 2 \text { parafin) }\end{array}$ \\
\hline Penjelasan & $\begin{array}{l}\text { Media } 1 \text { dipotong } 3 \times 2 \mathrm{~cm} \\
\text { diberikan air dengan cara di } \\
\text { teteskan, kurang dari } 03: 51 \\
\text { detik, air sudah menyebar } \\
\text { kepermukaan karton }\end{array}$ & $\begin{array}{l}\text { Media } 1 \text { dipotong } 3 \times 2 \mathrm{~cm} \\
\text { dilakukan tindakan dengan } \\
\text { cara mengoles dengan lem } \\
\text { kayu kemudian diberikan air } \\
\text { dengan cara di teteskan, } \\
\text { kurang dari } 18 \text { jam, air } \\
\text { berubah warna dan karton } \\
\text { masuk menyebar } \\
\text { kepermukaan karton }\end{array}$ & $\begin{array}{l}\text { Media 1 dipotong } 3 \times 2 \mathrm{~cm} \\
\text { diberikan paraffin dengan } \\
\text { cara mengolesnya } \\
\text { kemudian diberi air dengan } \\
\text { cara di teteskan, lebiih dari } \\
24 \text { jam karton masih terjaga } \\
\text { dari rembesan air kedalam } \\
\text { karton. }\end{array}$ \\
\hline Treatment & $\begin{array}{lr}\text { Karton pada packaging } \\
\text { tidak tahan dengan air dan } \\
\text { kelembapan } & \text { sehingga } \\
\text { mudah rusak } & \end{array}$ & $\begin{array}{l}\text { Karton dengan dilapisi } \\
\text { dengan lem kayu, akan } \\
\text { bertahan lama jika terkena air } \\
\text { tetapi air yang terkena } \\
\text { tersebut berubah warna, } \\
\text { Adanya zat kima jika terkena } \\
\text { air hal ini dampak dari } \\
\text { lapisan lem kayu. }\end{array}$ & $\begin{array}{l}\text { Karton dengan lapisan } \\
\text { paraffin dengan } \begin{array}{r}\text { cara } \\
\text { dioleskan }\end{array} \\
\text { menggunakan air, karton } \\
\text { masih kuat meskipun } \\
\text { terkesan kaku dan susah } \\
\text { dilipat, karena lapisan } \\
\text { paraffin menjadi kaku. }\end{array}$ \\
\hline Yang seharusnya & $\begin{array}{l}\text { Struktur kuat karena adanya } \\
\text { ply dalam karton yang } \\
\text { menjadikan kemasan kuat, } \\
\text { tetapi jika lembab karton } \\
\text { menjadi hancur }\end{array}$ & $\begin{array}{l}\text { Jika tidak ada zat kima jika } \\
\text { terkena air, eksplorasi ini } \\
\text { dapat digunakan. Maka } \\
\text { eksplorasi dengan pelapis } \\
\text { lem kayu tidak dapat } \\
\text { digunakan dan berbahaya. }\end{array}$ & $\begin{array}{l}\text { Kekakuan akibat dari } \\
\text { paraffin menjadi struktur } \\
\text { kemasan sebagai kekuatan } \\
\text { baik secara fungsi atau } \\
\text { secara daya tahan terhadap } \\
\text { cuaca. }\end{array}$ \\
\hline
\end{tabular}




\section{Post-test}

Pada bagian ini sudah dilakukan tindakan dari pre-test dan treatment sehingga post test diharapkan sudah sesuai dengan parameter yang sudah ditetapkan yaitu produk kemasan sudah tahan terhadap kelembapan. Adapun penjelasan sebagai berikut:

TABEL VII

HASIL POST-TEST

(Sumber. Peneliti)

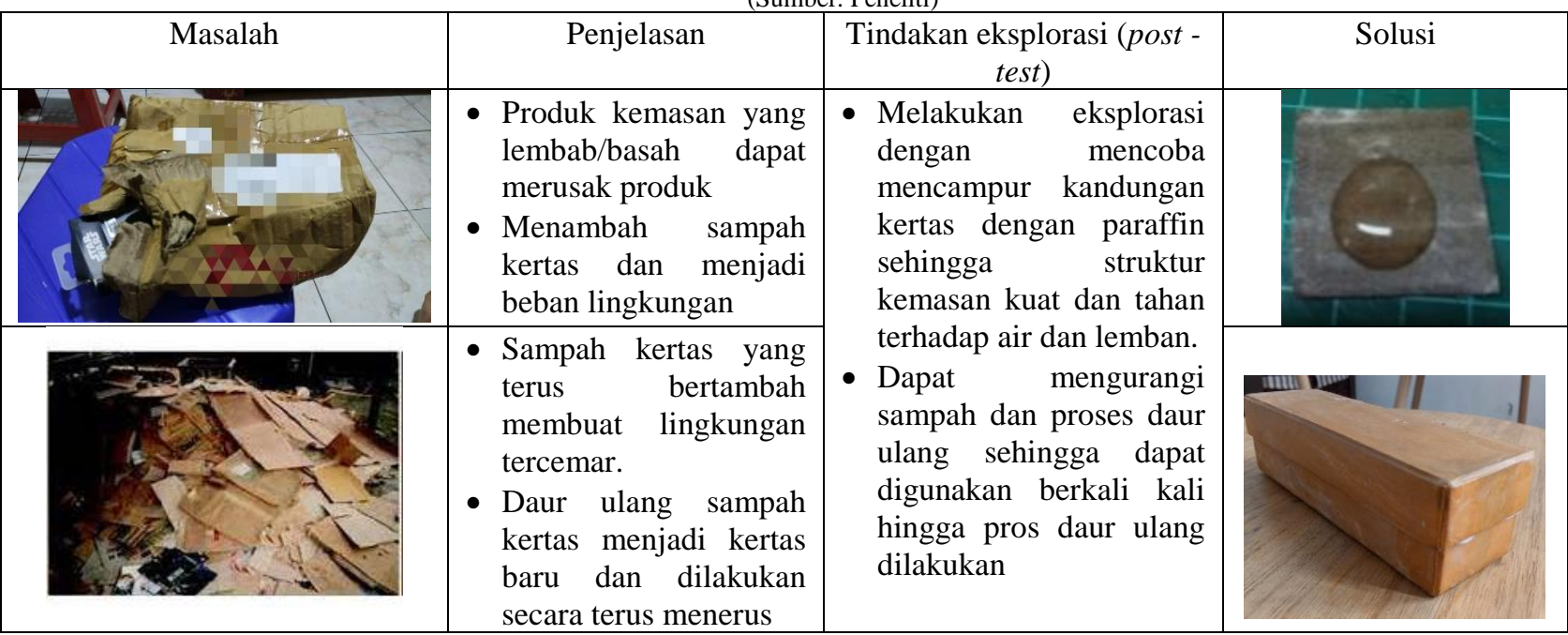

\section{KESIMPULAN}

Eksplorasi yang dilakukan dengan menggunakan pre-eksperiment one group pre-test - post-test, kertas karton dilakukan tindakan berulang untuk menghasilkan produk kemasan yang tahan terhadap air dan kelembapan, hal ini diuji cobakan dengan air dan rendaman, untuk dapat tahan terhadap air, kertas karton dilapisi dengan lem kayu dan paraffin. Hasil dari eksplorasi yaitu terdapat material yang unggul yaitu kertas karton dengan pelapis paraffin lebih unggul kelebihan lebih banyak dari kertas karton dengan menggunakan pelapis lem kayu. Sehingga kertas karton dengan menggunakan paraffin mampu tahan terhadap lembab dan air, dengan melakukan pencampuran ini visualisasi berubah menjadi gelap, tekstur menjadi kasar, struktur menjadi keras dan kuat. Percampuran ini mengurangi intensitas daur ulang sehingga produk kemasan masih bisa digunakan hingga saatnya harus dilakukan daur ulang.

\section{REFERENSI}

[1] Kementerian Lingkungan Hidup dan Kehutanan. (2017). Komposisi Sampah di Indonesia Didominasi Sampah Organik. Databoks, 2017. databoks.katadata.co.id/datapublish/2019/11/01/komposisi-sampah-di-indonesia-didominasi-sampah-organik

[2] Donoriyanto, D. S., Falah, Y., \& Azhar, M. F. (2020). Analisis Waste Pada Aktivitas Lini Produksi Dengan Menggunakan Lean Manufacturing Di Pt Abc. Tekmapro : Journal of Industrial Engineering and Management, 15(1), 25-35. https://doi.org/10.33005/tekmapro.v15i1.129

[3] Tracy Amelia, Yusita Kusumarini, L. B. (2018). Eksplorasi Material untuk Mebel dari Limbah Kertas Koran. Intra, 6(2), 572-579.

[4] Kotler dan Keller. 2009. Manajemen Pemasaran. Jilid I. Edisi ke 13. Jakarta: Erlangga.

[5] Klimchuk, Marianne dan Sandra A. Krasovec. 2006. Desain Kemasan. Jakarta: Erlangga.

[6] Rangkuti, Freddy. 2005. Analisis SWOT: Teknik Membedah Kasus Bisnis. Jakarta: Gramedia.

[7] Simamora, Bilson. 2007. Panduan Riset dan Perilaku Konsumen. Jakarta: Gramedia.

[8] Sugiyono. (2013). Metode Penelitian Kuantitatif, Kualitatif dan R\&D. Bandung: Alfabeta.CV

[9] Riduwan. 2013. Metode Dan Teknik Menyusun Tesis. Bandung. Alfabeta

[10] Campbell, D.T., Stanley, J. C. Experimental \& Quasi experimental Design for Research. Kalangan sendiri

[11] Andi Prastowo. (2011). Metode Penelitian Kualitatif dalam Perspektif Rancangan Penelitian. Jogjakarta: Ar-Ruzz Media 